\title{
PENGARUH INFUSA DAUN JAMBU BIJI (Psidium guajava Linn.) TERHADAP PERTUMBUHAN BAKTERI Escherichia coli SECARA IN VITRO
}

\author{
Fitri Nadifah ${ }^{1}$, Siti Fatimah ${ }^{2}$, Lisa Susanti ${ }^{3}$ \\ ${ }^{1,2,3}$ D3 Analis Kesehatan STIKes Guna Bangsa Yogyakarta
}

\begin{abstract}
Background: Diarrhea is still a major health problem in Indonesia. This is due to the lack of knowledge about society hygiene and sanitation as well as there are still many people who haven't got health access. Guava (Psidium guajava) is a plant that has long been known by locals as traditional medicine. Some research has shown that extracts of the guava flesh is effective as an antidiarrheal. In addition, guava possessed efficacy as an anti-inflammatory, anti-mutagenic, anti-microbial and analgesic.
\end{abstract}

Objective: To determine the effect of various concentrations of guava infusion leaves inhibiting $E$. coli growth in vitro.

Methods: Third, fourth and fifth leaf from the tip were used as the materials. Leaves infusion concentration used was $20 \%, 40 \%, 60 \%, 80 \%$ and $100 \%$. Each concentration infusion loaded into wells of Mueller-Hinton $(\mathrm{MH})$ agar media. Radical zone around the wells measured as bacterial growth inhibition. The data were analyzed using one way analysis of variance (One-way ANOVAs).

Results: There is the influence of infusion of guava leaves (Psidium guajava) on the growth of $E$. coli in vitro with a mean diameter of the smallest concentration of radicals zone which is $20 \%$ of $15.3 \mathrm{~mm}$ and the greatest concentration of $100 \%$ by $22 \mathrm{~mm}$.

Conclusion: Infusion of guava leaves have a strong influence in inhibiting $E$. coli growth as it has antibacterial chemical components.

Keywords: Anti-bacterial, guava (Psidium guajava), E. coli

\section{PENDAHULUAN}

Diare masih merupakan masalah kesehatan utama pada anak balita karena kebersihan yang kurang. Penyakit ini masih banyak ditemukan di negara berkembang, seperti Indonesia (Segeran, 2005). Setiap tahun terdapat 112.000 kasus kematian karena diare pada semua golongan umur, 55.000 kasus diantaranya terjadi pada balita (Depkes RI, 2000).

Penyakit diare disebabkan oleh bakteri $E$. coli. Bakteri ini bersifat oportunistik yang banyak ditemukan di dalam usus besar manusia sebagai flora normal. Selain itu bakteri ini juga dapat menyebabkan infeksi primer pada usus, misalnya diare, dan menimbulkan infeksi pada jaringan tubuh lain di luar usus (Karsinah, 1994).

Masyarakat pada umumnya telah banyak mengenal berbagai macam obat anti diare. Seiring berkembangnya pengetahuan, masyarakat juga semakin jeli memilih produk obat yang akan mereka konsumsi. Masyarakat menyadari bahwa obat-obatan yang mengandung bahan kimia lebih beresiko karena memiliki efek samping yang dapat merugikan kesehatan.

Tanaman jambu (Psidium guajava) dikenal oleh masyarakat Indonesia 
sebagai obat herbal yang dapat digunakan untuk mengobati berbagai penyakit. Masyarakat lokal di Indonesia menggunakan daun jambu biji sebagai anti diare. Beberapa penelitian tentang jambu biji, diantaranya oleh Novita (2012), menunjukkan bahwa jambu biji memiliki khasiat sebagai anti inflamasi, anti mutagenik, anti mikroba dan analgesik. Beberapa senyawa kimia yang terkandung dalam jambu biji antara lain polifenol, karoten, flavonoid dan tannin. Hasil penelitian Adnyana, dkk (2004) menunjukkan bahwa ekstrak etanol daun jambu biji daging buah putih memiliki kemampuan hambat bakteri yang lebih besar daripada jambu biji daging buah merah terhadap E. coli. Tujuan penelitian ini adalah untuk mengetahui pengaruh infusa daun jambu biji terhadap pertumbuhan bakteri $E$. coli secara in vitro.

\section{METODE PENELITIAN}

Obyek penelitian adalah daun jambu biji (Psidium guajava) jenis bangkok. Daun yang digunakan adalah daun ketiga, keempat dan kelima dari pucuk karena pada jenis daun ini terdapat banyak senyawa aktif. Infusa daun jambu biji dibuat dengan mengeringkan daun dalam oven suhu $60^{\circ} \mathrm{C}$ hingga kering. Daun yang kering ini disebut dengan simplisia. Simplisia sebanyak 5 gram dimasukkan dalam erlenmeyer yang berisi akuades

kemudian dipanaskan di atas penangas air suhu $90^{\circ} \mathrm{C}$. Air dari rebusan tersebut tersebut disaring sehingga didapatkan infusa $100 \%$. Infusa tersebut diencerkan dengan penambahan akuades sehingga didapatkan infusa konsentrasi $20 \%, 40 \%$, $60 \%, 80 \%$ dan $100 \%$ masing-masing dengan volume $1 \mathrm{ml}$.

Bakteri E. coli yang digunakan diperoleh dari Laboratorium Mikrobiologi Politeknik Kesehatan Yogyakarta. Media untuk pertumbuhan bakteri adalah Mueller-Hinton (MH). Masing-masing konsentrasi infusa daun jambu biji dimasukkan ke dalam sumuran pada media agar sebanyak $20 \mu \mathrm{l}$. Kemudian bakteri diinkubasi pada suhu $37^{\circ} \mathrm{C}$ selama 24 jam. Pengamatan dilakukan dengan mengukur diameter zona radikal atau zona hambat pertumbuhan bakteri di sekitar sumuran.

\section{HASIL DAN PEMBAHASAN}

Hasil pengamatan terhadap
pertumbuhan bakteri menunjukkan
adanya zona hambat pertumbuhan bakteri
di sekitar sumuran. Besarnya zona
hambat ini berbeda-beda pada masing-
masing konsentrasi infusa. Kontrol negatif
berupa akuades tidak menghasilkan zona
hambat yang artinya zona hambat pada
masing-masing konsentrasi infusa bukan
dari pengaruh akuades sebagai pelarut
(Gambar 1).
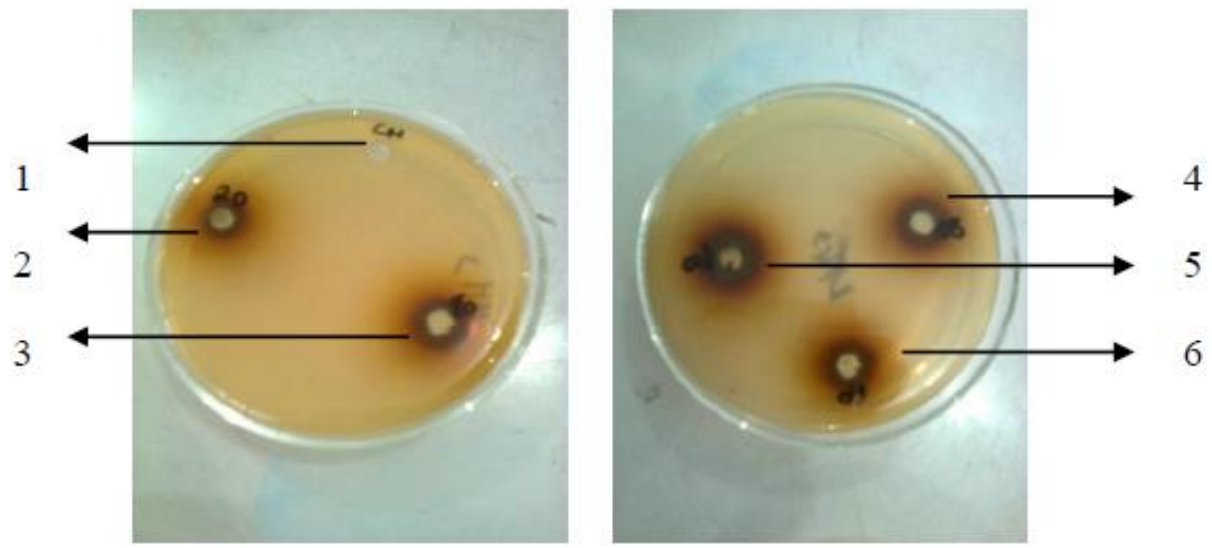

Gambar 1. Diameter zona hambat infusa daun jambu biji terhadap pertumbuhan $E$. coli pada media MHA. (1) Kontrol negatif berupa aquadest steril; (2) Konsentrasi infusa daun jambu biji 20\%; (3) Konsentrasi infusa daun jambu biji 40\%; (4) Konsentrasi infusa daun jambu biji 60\%; (5) Konsentrasi infusa daun jambu biji 80\%; (6) Konsentrasi infusa daun jambu biji 100\%. 
Diameter zona hambat paling rendah adalah pada konsentrasi infusa $20 \%$, sedangkan zona hambat paling tinggi adalah pada konsentrasi $100 \%$ (Tabel 1). Semakin tinggi konsentrasi infusa daun jambu biji maka semakin besar diameter zona hambat terhadap pertumbuhan bakteri $E$. coli. Hal ini dapat dilihat dengan adanya peningkatan diameter zona hambat seiring dengan peningkatan konsentrasi infusa daun jambu biji.

Tabel 1. Hasil pengukuran diameter zona hambat infusa daun jambu biji

\begin{tabular}{|c|c|c|c|c|c|c|}
\hline \multirow{2}{*}{ Ulangan } & \multicolumn{7}{|c|}{ Diameter zona hambat (mm) } \\
\cline { 2 - 7 } & Kontrol - & $\mathbf{2 0} \%$ & $\mathbf{4 0} \%$ & $\mathbf{6 0 \%}$ & $\mathbf{8 0} \%$ & $\mathbf{1 0 0} \%$ \\
\hline 1 & 0 & 16 & 17 & 19 & 20 & 23 \\
\hline 2 & 0 & 15 & 16 & 18 & 20 & 21 \\
\hline 3 & 0 & 15 & 17 & 19 & 19 & 22 \\
\hline Rata-rata & 0 & 15,3 & 16,6 & 18,6 & 19,6 & 22 \\
\hline
\end{tabular}

Uji statistik menggunakan analisis varian satu arah bertujuan mengetahui perbedaan diameter zona radikal dengan menggunakan SPSS 17 for windows dengan tingkat kepercayaan $95 \%$. Berdasarkan perhitungan, nilai $\mathrm{F}$ adalah 43.429 dengan signifikan sebesar 0.000 yang kemudian jika dibandingkan dengan nilai $F$ tabel dengan df pembilang 4 dan df penyebut 10 untuk signifikasi 0.05 sebesar 3.48 , jadi $F$ hitung lebih besar dari $F$ tabel $(43.429>3.48)$ dan signifikasi lebih kecil dari $0.05(0.000<0.05)$. Dengan demikian dari hipotesis yang diajukan, Ho ditolak dan $\mathrm{Ha}$ diterima sehingga ada pengaruh dari peningkatan berbagai konsentrasi infusa daun jambu biji terhadap zona hambat pertumbuhan bakteri E. coli. Hasil uji regresi menunjukkan bahwa nilai $R$ kuadrat sebesar 0.934 yang berarti besarnya pengaruh variabel bebas (infusa daun jambu biji) terhadap variabel terikat (diameter zona hambat) adalah 93.4\% sedangkan sisanya yaitu $6.6 \%$ dapat dipengaruhi oleh faktor lain selain variabel bebas.

Hasil pengukuran diameter zona hambat menunjukkan adanya pengaruh yang signifikan dari infusa daun jambu biji terhadap pertumbuhan bakteri $E$. coli. Hasil ini sesuai dengan penelitian Rahayu (2008) bahwa rebusan daun jambu biji konsentrasi $10 \%$ sudah menghasilkan zona radikal dengan diameter $11 \mathrm{~mm}$. Kemampuan dalam menghambat pertumbuhan bakteri ini dikarenakan daun jambu biji mengandung sejumlah senyawa aktif yang berperan sebagai anti bakteri, seperti senyawa fenol yang terdiri atas tanin dan flavonoid. Mekanisme atau cara kerja senyawa fenol dalam hal ini adalah tanin dan flavonoid dalam menghambat pertumbuhan bakteri dengan cara denaturasi protein serta merusak membran sel yang menyebabkan enzim inaktif (Pelczar dan Chan, 2008).

Penggunaan infusa dimaksudkan agar dapat langsung diaplikasikan dalam menghambat pertumbuhan bakteri $E$. coli, terutama dalam pengobatan diare. Menurut Novita (2012) daun jambu biji dapat langsung diaplikasikan langsung kepada masyarakat terutama pada penderita diare dengan cara mengunyah 3 lembar daun jambu biji muda yang segar dengan sedikit garam lalu ditelan, lakukan 2 kali sehari.

\section{KESIMPULAN}

Infusa daun jambu biji memiliki pengaruh signifikan dalam menghambat pertumbuhan bakteri E. coli. Diameter zona hambat paling rendah adalah pada konsentrasi infusa $20 \%$, sedangkan zona hambat paling tinggi adalah pada konsentrasi $100 \%$. Senyawa dalam daun jambu biji yang berperan sebagai antibakteri adalah senyawa fenol yang terdiri atas tanin dan flavonoid. Pembuatan infusa daun jambu biji yang relatif mudah diharapkan dapat langsung diaplikasikan oleh masyarakat dalam mengobati penyakit yang disebabkan oleh infeksi bakteri $E$. coli, seperti penyakit diare. 


\section{DAFTAR PUSTAKA}

Adnyana, I.K., E. Yulinah, J.I. Sigit, Neng Fisheri K., dan M. Insanu. 2004. Efek ekstrak daun jambu biji dagin buah putih dan jambu biji daging buah merah sebagai antidiare. Acta Pharmaceutica Indonesia Vol. XXIX No. 1.

Depkes RI. 2000. Buku Pedoman Pelaksanaan Program P2 Diare. Depkes RI: Jakarta.

Karsinah. 1994. Buku Ajar Mikrobiologi Kedokteran Edisi Revisi oleh Staf Pengajar Fak. Kedokteran UI. Binarupa Aksara. Jakarta

Novita, A.,P., 2012, Pengaruh Air Rebusan Daun Jambu Biji (Psidium guajava) terhadap Pertumbuhan Escherichia coli Patogen, KTI Universitas Muhammadiyah Surabaya.

Pelczar dan E.C.S. Chan. 2008,DasarDasar Mikrobiologi. Ul. Jakarta.

Rahayu, A. 2008, Pengaruh daya antibakteri rebusan daun jambu biji terhadap pertumbuhan Staphylococcus aureus secara in vitro. Karya Tulis IImiah. Politeknik Kesehatan Prodi Analis Kesehatan. Yogyakarta.

Segeren. 2005. Faktor Resiko Kejadian Hipernetremia pada Anak Balita Dengan Diare Cair Akut. Vol 37. No.4. Desember 2005: 198-203 